\title{
Examining Consumer Ethnocentrism amongst Jordanians from an Ethnic Group Perspective
}

\author{
Saeb Farhan Al Ganideh (Corresponding author) \\ Department of Marketing, Al Zaytoonah University of Jordan \\ PO box 130, Amman 11733, Jordan \\ Tel: 962-6-429-1511Ｅ-mail: saebfarhan@yahoo.co.uk
}

Hameed Al Taee

Department of Marketing, Al Zaytoonah University of Jordan

PO box 130, Amman 11733, Jordan

Tel: 962-6-429-1511_E-mail: altaee47@yahoo.com

Received: April 21, $2011 \quad$ Accepted: December 4, $2011 \quad$ Published: February 1, 2012
doi:10.5539/ijms.v4n1p48

\begin{abstract}
Consumer ethnocentrism literature has focused on examining ethnocentric tendencies among consumers from developed countries utilizing the well-known consumer ethnocentrism scale. This study aims to measure Jordanian consumers' ethnocentric tendencies towards Arabian products and to explore how such ethnocentric tendencies vary based on their demographic variables. Data were collected from a total of 372 Arab Jordanian consumers who live in Amman city during the winter of 2008. The findings of the current study indicate that Jordanian consumers have strong ethnocentric tendencies towards purchasing products of Arab countries. Moreover, the findings reveal that Jordanian consumers' ethnocentric tendencies towards purchasing Arabian products did not vary by gender, marital status, income and age. However, geographical location proved to have significant influence on Jordanians' ethnocentric tendencies towards products made in Arab countries. Overall, the concept of consumer ethnocentrism can help Arab and global marketers to develop more effective marketing strategies.
\end{abstract}

Keywords: Consumer ethnocentrism, CETSCALE, Jordan, Arab, Demographics

\section{Introduction}

Overall, the globalization of markets has increased the competition between the domestic and foreign brands (Nguyen, Nguyen, \& Barrett, 2008). Emerging countries' products are starting to compete in a globalised world with products originating from developed countries. However, globalisation does not mean simply mean that all consumers all around the world are globalising and do have the same tastes (Cleveland, Laroche, \& Papadopoulos, 2009). Differences between individuals in different spots of the world still exist due to diversities in culture, history and geography (Laroche, Papadopoulos, Heslop, \& Bergeron, 2003; Wang \& Heitmeyer, 2006). Developing countries have been ignored in most of international business research (Al Ganideh, 2010). For example, little attention has been paid from international business researchers to Arab consumers. The recent wave of popular protests in Arab countries namely, Tunisia, Egypt, Libya, Syria, Bahrain, and Yemen led and sparked by young Arab generations who are looking forward to freedom and democracy should encourage more researchers all over the world to explore more insights regarding purchasing and consumption patterns of Arab consumers. Today, in most of developing countries, consumers have more choices than ever before. Intensive competition between companies and social networks has empowered consumers, in particular in developing countries, and has led them to be familiar with more products and brands from overseas countries (Tripathi, 2009). For instance, in Arab countries social networking sites such as Facebook have ignited and motivated the Arab Uprisings.

It is of crucial importance to indicate that local and global marketers are concerned with satisfying global consumers. Local marketers' survival is continually threatened by international competitors (Steenkamp \& Jong, 
2010). It is clear that some consumers who perceive themselves as globalized consumers express negative biases towards foreign products (Suh \& Smith, 2008). In this context, local marketers, particularly in the developing countries, can build on such negative feelings to motivate nationals to purchase their domestic products in order to support their country's economy and to reduce high unemployment.

\section{Literature review}

The consumer ethnocentrism concept could explain why some consumers have negative attitudes towards foreign products (Shimp, 1984) and can help researchers to justify consumers' bias towards purchasing foreign and home country products (Hsu \& Nien, 2008). It can improve the understanding of how consumers evaluate domestic and foreign products (Shimp \& Sharma, 1987). Over the last two decades, the concept of ethnocentrism has expanded to consumer behavior. Psychologists have extended ethnocentrism at the level of the person, where it relates to natural tendency of people to refer themselves to values and ways of thinking of their own ethnic group (Usunier \& Lee, 2005). Ethnic feeling has become a major motivation in consumer consumption behavior in the contemporary marketing context (Vida \& Fairhurst, 1999) and has a more powerful impact on consumers' domestic products bias than marketing mix (Herche, 1994). Generally, international marketing literature can be criticized as it has mainly focused on examining negative feelings that might prevent consumers from purchasing foreign products and has ignored exploring positive feelings that might stimulate consumers to purchase foreign countries' products (Maher, Clark, \& Maher, 2010; Oberecker \& Diamantopoulos, 2011). For example, a number of recent international business studies have focused on exploring feelings of hostility that consumers might harbor towards a certain country and how such feelings of animosity affect the intention to buy products imported from that country (i.e Funk, Arthurs, Treviño, \& Joireman, 2010; Guido, Prete, Tedeschi, \& Dadusc, 2010; Smith \& Qianpin , 2010; Hoffmann, Mai, \& Smirnova , 2011). In contrast, a number of researchers have focused on how admiration and favorable emotions consumers might express towards products sourced from a particular admired country can lead to a favorable perception towards that country's products (i.e Paswan \& Sharma, 2004; Maher et al., 2010). Exploring more insights regarding domestic and foreign products' consumption can help international marketing managers to conduct more effective global marketing strategies.

\subsection{The concept of consumer ethnocentrism}

It is of crucial importance to highlight that most researchers agreed that 'ethnocentrism' was introduced for the first time by an early work for Sumner in 1906. It is obvious that ethnocentrism is a sociological concept refers to beliefs and philosophy of one's own group as superior and centre of everything (Caruana, 1996). The concept of ethnocentrism, 'ethno' meaning group and 'centrism' meaning centred (Usunier \& Lee, 2005). Sumner (1906, p.13) stated that ethnocentrism is viewing things in way that one's own group is the centre of everything and evaluating and scaling things based on one's own group standers. Lynn (1976) argued that ethnocentrism can be considered as a part of the humankind nature. It involves dual judgments; a positive attitude towards one's own group and a negative attitude towards other groups (Chang \& Ritter, 1976). Shone (2004) argued that, although Sumner is one of the founders of sociology and is well known for originating the concepts of folkways, ethnocentrism and cultural relativism, he did not believe that human beings are equal.

The concept of consumer ethnocentrism was developed by Shimp and Sharma in 1987 based on the sociological and psychological perspectives of the concept of ethnocentrism which was conceptualized earlier by Sumner in 1906. The concept of consumer ethnocentrism was designed to capture consumer emotions related to purchasing products from foreign countries (Shimp, 1984). According to Shimp and Sharma (1987) consumer ethnocentrism gives the individuals a sense of identity, feelings of belongings to the in-group. Thus, ethnocentric tendencies represent the emotional dimension of buying foreign products as well as the implication that the choice somehow threatens domestic industry and national security (Herche, 1992). Ethnocentric tendencies in consumers are a part of a constellation of social-psychological and demographic influences (Sharma, Shimp, \& Shin, 1995). Overall, ethnocentrism entails a tendency in the individuals to be ethnically centred and to be stiff in their acceptance of the 'alike' culture and its individuals and in their rejection of the 'unalike' culture and its individuals (Durvasula, Andrews, \& Netemeyer, 1997). Shimp and Sharma (1987) defined consumer ethnocentrism as 'The beliefs held by the consumers about the appropriateness, indeed morality, of purchasing foreign made products' (p.240). Ethnocentric tendencies represent the emotional dimension of buying foreign products as well as the implication that the choice somehow threatens domestic industry and national security (Herche, 1992). Ethnocentric consumers do believe that buying foreign-made products is morally wrong; thus foreign made products may become objects of contempt. Nevertheless, non-ethnocentric consumers evaluate foreign products based on their features or even see them as better since they are not originated from consumer's own country. Overall, consumer ethnocentrism is appraised as a tool that is likely to be utilized to identify consumers who prefer to purchase domestic products to foreign goods (Guneren \& Ozturn, 2008). Consumers 
with high ethnocentric tendencies believe that purchasing foreign-made products is morally wrong; consequently foreign made products may become objects of contempt. On the other end of the continuum, highly non-ethnocentric consumers evaluate foreign products based on their attributes or even see them as better since they are not originated from consumer's own country (Vida \& Fairhust, 1999). High ethnocentric consumers evaluate products based on the moral acceptability of purchasing foreign products (Huddleston, Good, \& Stoel, 2001). They do not like to learn about foreign brands and products, since their processing of foreign products is superficial (Supphellen \& Gronnhaung, 2003). Purchasing foreign products is perceived by some consumers as immoral since it has an adverse impact on the national economy. Ethnocentric attitudes transfer directly to negative views of advertisements and consequently transfer indirectly to the brands in developing economies while in advanced economies there is a lower degree of transference of ethnocentricity to advertisement attitude (Reardon, Miller, Vida, \& Kim, 2005).

Previous consumer ethnocentrism literature focused on examining ethnocentrism amongst consumers mainly in North America, Europe and China (i.e Bruning, 1997; Lee, Hong, \& Lee, 2003; Javalgi, Khare, Gross, \& Scherer, 2005; Evanschitzky,Wangenheim, Woisetschlager, \& Blut, 2008; Cleveland et al.,2009; Wang, Doss, Guo, \& Li, 2010). More specifically, the literature on consumer ethnocentrism focused on ascertaining consumer ethnocentric tendencies among the consumers mainly in the U.S.A (i.e Shimp, 1984; Brodowsky, Tan, \& Meilich, 2004) and in East of Europe (i.e Good \& Huddleston, 1995; Reardon et al., 2005; Cleveland et al., 2009). A number of studies have been conducted in Southern Europe and Mediterranean countries (Kaynak \& Kara 2002; Javalgi et al., 2005; Cleveland et al., 2009), in Oceania (i.e Ettenson \& Klein, 2005), and in East of Asia (i.e Sharma et al., 1995; O'Cass \& Lim, 2002; Cleveland et al., 2009). Some countries attempt to increase the consumer ethnocentrism level of their customers, and it is not surprising since domestic companies and organisations in most developing countries seek to survive against the strong competitors from the developed countries. The ethnocentrism concept helps local companies and government officials in conducting successful public campaigns to promote attributes of domestic products (Vida \& Fairhurst, 1999). Many countries conducted national campaigns to encourage consumers to buy domestic products and to increase the consumer ethnocentrism level of their citizens. The 'Made in ...' campaigns try to increase consumers' awareness towards their home country products and encourage them to buy their domestic products rather than foreign ones (Quester, Marr, \&Yeoh, 1996). The researchers maintained that many campaigns 'Buy Australian' were conducted in Australia to encourage consumers to buy their domestic products in 1923, 1958, 1982 and 1993. For example, the 1958 campaign targeted the Australian women; whereas the campaign organised in 1993 'Buy your kids a job' informed consumers that buying Australian would keep them and their sons and daughters working. Bruning (1997) argued that research has approved that national advertising campaigns 'Made in U.S.A' and 'Buy Canada' are useful in convincing consumers to buy their national products. Moreover, in the Czech Republic the government conducted a campaign to encourage Czech consumers to buy their national products (Balabanis, Diamantopoulos, Mueller, \& Melewar, 2001). Additionally, in the U.S.A following the September 11 climate, many companies have tried to get benefits from the strong patriotism for American consumers by conducting campaigns to encourage them to buy their national products (Lee et al., 2003). Also, Russian companies conduct many public campaigns and advertisements to trigger Russian consumers' nationalism and patriotism (Supphellen \& Gronhaug, 2003). A campaign 'Buy Korean' was conducted in South Korea in 2003 to encourage Koreans to buy their national products and to boycott foreign brands (Phau \& Chan, 2003). Thailand also conducted a campaign 'Thai buy Thai' to encourage the Thais to buy Thai products during the Asian crisis (Ang, Jung, Leong, Pornpitakpan, \& Tan, 2004).

In opposition to the above background, international companies attempt to resist the strong national feeling by localising the brand; for example, McDonald's has adopted this strategy by introducing specific products matching local tastes to reduce ethnocentric tendencies towards the restaurant branches' all over the world (Ang et al., 2004). For example, in the Middle East and North Africa region (Arab countries) McDonald's has recently introduced a very good selling burger (Mac Arabi). In order to target consumers with ethnocentric tendencies successfully, brand names, packages and advertising messages may need to use national symbols and stress domestic content (Witkowski \& Beach, 1998). In this context, it is important for international companies and organisations to conduct training programs for top managers to reduce their ethnocentrism and to enhance their moral philosophy.

\subsection{Consumer ethnocentrism scale (CETSCALE)}

Shimp and Sharma (1987) developed a consumer ethnocentrism scale (CETSCALE) based on socio-psychological literature to measure consumers' ethnocentrism for purchasing American versus foreign made products. The scale has been constructed based on the views of 863 American citizens who were asked to 
state their views on whether it is appropriate or not to purchase foreign products (Shimp, 1984). The researchers indicated that their scale can clarify why some consumers evaluate national products more favourably than foreign products. Hence, the CETSCALE has been considered a central contribution to consumer research (Kaynak \& Kara, 2002; Al Ganideh, 2010). The CETSCALE (17-item 7-point Likert scale) is the predominant used scale in marketing research to measure consumers' ethnocentric tendencies and it has been used by the vast majority of consumer ethnocentrism studies (i.e Javalgi et al., 2005; Klein, Ettenson, \& Krishnan, 2006; Al Ganideh, Jackson, \& Marr, 2007; Evanschitzky et al.,2008; Cleveland et al.,2009; Wang et al.,2010). All the 17 items of the CETSCALE are linked to the idea of whether buying foreign products hurts the domestic economy, causes unemployment and is unpatriotic (Lindquist, Vida, Plank, \& Fairhurst, 2001). Nevertheless, the scale can be criticised as it does not classify consumers to ethnocentric or non-ethnocentric, however, all consumers based on the CETSCALE are ethnocentric and their ethnocentrism level ranges from 17 to 119 . Moreover, the CETSCALE does not provide international marketers with precise facts concerning a particular country or a particular product. Bawa (2004) criticised the CETSCALE as it adheres to the viewpoint that consumer ethnocentrism is a question of 'how ethnocentric' and not 'whether ethnocentric'.

The CETSCALE has been developed based on the sociological concept of ethnocentrism which entails scaling and rating people and objects from other cultures and ethnicities based from one's own ethnic group cultural perspective. However, the scale has only been employed to explore consumers' ethnocentric tendencies towards their national products. Previous consumer ethnocentrism research examined consumers' ethnocentric tendencies towards their national products using national versions of the CETSCALE (i.e American; British; German; Jordanian; Chinese; Korean; Russian). The current study aims to explore whether the scale can be applicable in terms of products originating from foreign countries of the same ethnic groups of consumers' domestic country. The CETSCALE has been developed to help researchers and marketers to examine ethnocentric tendencies of particular country consumers towards their national products. However, this study aims to examine Jordanians ethnocentric tendencies towards products sourced from Arab countries rather than towards their national products employing Arabian version of the CETSCALE.

It is important for local and global marketers to consider consumers' demographics in targeted markets while developing their strategies (Javalgi et al., 2005). Exploring the effect of demographic variables on consumer ethnocentrism can help marketers to differentiate consumers based on their positive and negative preferences towards foreign and domestic products (Shankarmahesh, 2006). However, the literature of consumer ethnocentrism does not provide a clear picture regarding the effect of demographics on foreign product evaluation. Hence, there is a clear need to focus more on how various subgroups within a particular country assess and evaluate foreign products. International companies should not stay away from high ethnocentric consumers but need to modify their communication strategies to withdraw consumer's attention from products' country-of-origin.

Exploring the extent to which Jordanian consumers express ethnocentric tendencies towards Arabian products is beneficial. Jordan's foreign trade volume with Arab countries has grown enormously in the last decade. As Table 1 shows Jordan's economy is highly dependent on Arab countries. According to the 2009 estimates, Jordan's exports to the Arab countries have exceeded 50 per cent of the total Jordanian exports. Iraq, Saudi Arabia, Syria, United Arab Eremites, Lebanon and Egypt are of the major Arab markets for the Jordanian products. More than 30 per cent of the total Jordanian imported products originating from Arab countries. Imported products from Arab countries include products such as food, beverages, live animals, and crude Oil (CBJ, 2009).

\section{Insert Table 1here}

Overall, the current research extends consumer ethnocentrism research as it aims to explore Jordanian consumers' ethnocentric tendencies towards Arab products utilizing an ethnic version of the CETSCALE. Moreover, it examines the effect of demographic variables (gender, marital status, income, age and geographical location) on an ethnic version of the CETSCALE.

\section{Methodology}

Arab consumers have different lifestyles to their Western and Asian counterparts who have been the main subjects in previous consumer ethnocentrism literature. Arab consumers have been ignored totally in most of international marketing research. Thus, more attention should be paid from international marketing and business researchers to Arab consumers particularly with the continued wave of uprisings which is hitting the majority of Arab countries asking for more freedom and more equality. The Arab spring has started with the fall of Egypt and Tunisia regimes in one month. The winds of change are blowing strongly countries such as Yemen and Syria. Arabian states (22 countries and territories and 358 million people) are stretching from the Arabian (Persian) 
Gulf in the east to the Atlantic Ocean in the west, and from the Mediterranean Sea in the north to the Sahara Desert and the Indian Ocean in the south. The Arabic language and the religion of Islam form the unifying features of the Arab World. The vast majority of people in the Arab World adhere to the Arabian ethnicity. The Arabian identity promoted extensively by the leaders and the governments of the Arabian states. Economic, political, social and sport programs are extremely strong between the Arab states. Jordan is a good representative of the Arab countries as more than 99 per cent of its population are Arabs. The population of Jordan was estimated at nearly 6 million in 2010 at an annual rate of 2.2 (DOS, 2010).

To examine Jordanians' ethnocentrism tendencies towards purchasing Arabian products data were collected from 372 mall shoppers in Amman city (the capital of Jordan) over a five week period during the winter of 2008. The respondents were from one of the three categories, these were: first, residents of the central part of Jordan, creating the largest response sector of 67.2 per cent, followed by residents of the northern part of Jordan with 19.8 per cent, and finally 13 per cent of the respondents were from the southern part of the country. The respondents were asked to answer a short 10-item ethnic version (Arabian) of Shimp and Sharma's CETSCALE (i.e only those products that are unavailable in Arab countries should be imported; Arab products, first, last, and foremost; purchasing foreign-made products is un-Arabian). Although the CETSCALE originally was developed based on ethnic perspective, previous research applied the CETSCALE based on nationalities (i.e American; British; Chinese; German; Jordanian) in order to examine domestic consumers' ethnocentric tendencies towards their national products. Nevertheless, the current study has utilised the CETSCALE to explore Arab Jordanians' ethnocentric tendencies towards Arabian products (products which originating from Arab countries other than Jordan). An ethnic version of the CETSCALE proved to be very reliable with 0.925 Cronbach's Alpha for 10 item CETSCALE (Arabian version). The results of this study confirm the previous research that the CETSACLE is a reliable tool (i.e Javalgi et al., 2005; Al Ganideh et al., 2007; Guneren \& Ozturn, 2008).

\section{Discussion of results}

Overall, the results showed that Arab Jordanians have high ethnocentric tendencies towards products made in the Arab countries. The respondents' responses have a mean of 4.09. The means for the CETSCALE items range from 3.44 to 4.68 . The range for the responses is 1.24 . The score of the CETSCALE is 40.89 out of 70.00 and the standard deviation for the scale is 12.80 . Table 2 shows the mean for each item of the 10 item CETSCALE (Arabian version).

\section{Insert Table 2 here}

Strong ethnocentric tendencies Jordanians show towards Arabian products could be attributed to strong ethnic sentiments for those consumers knowing that the concept of consumer ethnocentrism had been originated from the ethnocentrism literature. Ethnocentric consumers believe that buying foreign products hurts the domestic economy, causes unemployment and is unpatriotic (Shimp \& Sharma, 1987). Hence, the high unemployment in Jordan could be also the reason behind the high ethnocentrism Jordanian consumers express towards Arabian countries' products. Official estimates place unemployment in Jordan at more than 13 per cent for 2010 (DOS, 2010), with unofficial estimates reaching as high as 27 per cent. Jordanians do believe that buying Arabian made products might help them in getting jobs as the Arabian Gulf countries hire hundreds of thousands of Jordanians. However, the uniformity of Jordanians ethnicity as more than 99 per cent of them are Arabs could be behind the high level of consumer ethnocentrism for Jordanians. In this context, Phau \& Chan (2003) indicated that the high level of consumer ethnocentrism for any country could be a result of high level of national heritage or the uniformity of ethnic groups and races for that country. The uniformity of ethnic groups and races can lead to high ethnocentric tendencies for consumers from a particular country (Al Ganideh et al., 2007).

The second objective of this study examines the effect of demographic variables (gender, marital status, income, age and geographical location) on an Arabian version of the CETSCALE to explore ethnocentric tendencies for various subgroups within the Jordanian society towards purchasing Arabian products. Table 3 shows that the results of ANOVA test for the model which proved to be statistically significant $(\mathrm{F}=5.337)(\mathrm{df}=5,366)$. The predictors namely, gender, marital status, income, age and geographical location explain only 6.8 per cent of the total variance in the Arabian version of CETSCALE.

\section{Insert Table 3 here}

To examine the influence of demographic variables namely, gender, marital status, income, age and geographical location on the CETSCALE (Arabian version) regression technique was carried out. Table 3 shows the results of conducting linear regression on gender, marital status, income, age and geographical location as independent variables and the CETSCALE (Arabian version) as a dependent variable. Overall, the results of this study prove that Jordanian ethnocentric tendencies towards Arabian products did not vary by gender, marital status, income 
and age. However, the results of this study show that geographical location has a significant influence on the CETSCALE (Arabian version). Consumers from the south of Jordan have more ethnocentric tendencies than their counterparts from the centre and the north of Jordan towards products originating from Arab countries. This could be attributed as those consumers less exposed to other cultures than their counterparts from the north and the centre of the country. The consumer ethnocentrism concept could help Arab marketers as well as Arab officials to conduct successful public campaigns to promote the features and attributes of Arab products and the importance of purchasing Arab products to support the Arab economies. Arab marketers should stress in their promotional campaigns on the Arabian country-of-origin for their products. On the other hand, foreign international marketers should not avoid ethnocentric Arab consumers. Nevertheless, they should target them in a way that drives those consumers away from products' country-of-origin. International marketers should be cautious while using a foreign country label in their promotions in Jordan and Arab countries. Rather, they should highlight issues such as product quality and price consideration in an attempt to reduce ethnocentrism amongst Jordanians and Arabs consumers. In addition, international marketers are strongly recommended to localise their brands in the markets of the Arab countries. They should amend their communication strategies in a way deflect Jordanian and Arab consumers' attention from the foreign brand names and instead make use of domestic or Arabian brand names and national or Arabian symbols. Domestic or Arabian associations could make foreign products more acceptable to Jordanian and Arab ethnocentric consumers. In this regard, fast food giants like McDonald's and KFC have adopted this strategy by introducing many products in Jordan and the Arab states with Arabian brand names to reduce Arabs' ethnocentric tendencies towards the two restaurants and their products. Although it is not easy to reduce consumer ethnocentrism it will be useful for international marketers to target Jordanians and Arabs by positioning their products closer to that of the local (Arab) country products. Generally, it could be valuable for international companies and organisations conducting their business in Jordan and the Arab world to conduct training programs for their marketing managers to improve their knowledge regarding how to deal with Arab consumers who have strong ethnocentric tendencies towards products made in Arab countries.

\section{Conclusions and marketing implications}

The results from this study proved that the CETSCALE (Arabian Version) is a reliable instrument. Jordanian and Arab marketers and manufactures could make Arabian ethnocentrism more powerful by improving the quality of Arabian products. It would seem that using one Arabian brand name for all the Arab states including Jordan might help to save the company's money and effort, as consumer ethnocentrism (Arab products) was found to be high for the Jordanian consumers. Also, it would seem that companies and organisations need to adjust their marketing communications strategies based on the demographics and ethnocentric tendencies of the target consumers. However, traditional segmenting variables, such as geographic and demographic, remain significant. It could be useful for local and international marketers not to deal with Jordan as one geographical segment. It would seem that international companies need to localise their brands to decrease the influence of the relatively high consumer ethnocentrism towards products sourced from Arab countries.

Two caveats for this research are obvious. Data were collected only from Jordanian subjects to represent consumers from 22 Arab countries. Moreover, the sample was limited to mall shoppers from Amman city to stand for the whole Jordanian society. Thus, it will be vital for further research to measure ethnocentric tendencies for Arab consumers towards Arabian products employing samples from Arab countries other than Jordan. Examining ethnocentric tendencies for consumers from countries such as Egypt, Lebanon, Algeria Tunisia, Syria, Libya and Yemen should be beneficial to the research in the area of consumer ethnocentrism. This study has only examined the influence of demographic variables on consumer ethnocentric tendencies for Arab consumers. Future research should explore additional antecedents to consumer ethnocentrism such as racial superiority and nationalism.

\section{References}

Al Ganideh, S.F., Jackson, H., \& Marr, N. (2007). An investigation into ethnocentrism among young Jordanians. World Journal of Retail Business Management, 2(1), 40-51.

Ang, S., Jung, K., Leong, S., Pornpitakpan, C., \& Tan, S. (2004). Animosity towards economic giants: what the little guys think. Journal of Consumer Marking, 21 (3), 190-207. http://dx.doi.org/10.1108/07363760410534740

Balabanis, G., Diamantopoulos, A., Mueller, R., \& Melewar, T. (2001). The impact of nationalism, patriotism and internationalism on consumer ethnocentric tendencies. Journal of International Business Studies, 32 (1), $157-175$. 
Bawa, A. (2004). Consumer ethnocentrism: CETSCALE validation and measurement of extent. VIKALPA, 29 (3), 43-57.

Brodowsky, G., Tan, J., \& Meilich, O. (2004). Managing country-of-origin: competitive advantages and opportunities. International Business Review, 13, 729-748. http://dx.doi.org/10.1016/j.ibusrev.2004.09.007

Bruning, E. R. (1997). Country of origin, national loyalty and product choice: the case of international air travel. International Marketing Review, 14 (1), 59-74. http://dx.doi.org/10.1108/02651339710159215

Caruana, A. (1996). The effects of dogmatism and social class variables on consumer ethnocentrism in Malta. Marketing Inelegance and Planning, 14 (4), 39-44. http://dx.doi.org/10.1108/02634509610121569

Central Bank of Jordan (CBJ). (2009). Central Bank of Jordan statistics for the Jordanian foreign trade sector. Central Bank of Jordan Publications, 2009.

Chang, E. C., \& Ritter, E. H. (1976). Ethnocentrism in black college students. The Journal of Social Psychology, 100, 89-98. http://dx.doi.org/10.1080/00224545.1976.9711910

Cleveland, M., Laroche, M., \& Papadopoulos, N. (2009). Cosmopolitanism, consumer ethnocentrism and materialism: an eight-country study of antecedents and outcomes. Journal of International Marketing, 17(1), 116-146. http://dx.doi.org/10.1509/jimk.17.1.116

Department of Statistics (DOS). (2010). Jordan Statistics 2010 Year Book. Jordanian Department of Statistics Publications, 2010.

Durvasula, S., Andrews, J., \& Netemeyer, R. (1997). A cross-cultural comparison of consumer ethnocentrism in the United States and Russia. Journal of International Consumer Marketing, 9 (4), 73-93. http://dx.doi.org/10.1300/J046v09n04_05

Ettenson, R., \& Klein, J. (2005). The fallout from French nuclear testing in the South Pacific: a longitudinal study of consumer boycotts. International Marketing Review, 22 (2), 199-224. http://dx.doi.org/10.1108/02651330510593278

Evanschitzky, H., Wangenheim, F., Woisetschlager, D., \& Blut, M. (2008). Consumer ethnocentrism in the German market. International Marketing Review, 25(1), 7-32. http://dx.doi.org/10.1108/02651330810851863

Funk, C. A., Arthurs, J. D., Treviño, L. J., \& Joireman, J. (2010). Consumer animosity in the global value chain: the effect of international production shifts on willingness to purchase hybrid products. Journal of International Business Studies, 41(4), 639-651. http://dx.doi.org/10.1057/jibs.2009.29

Good, L., \& Huddleston, P. (1995). Ethnocentrism of Polish and Russian consumers: are feelings and intentions related? International Marketing Review, 12 (5), 35-48. http://dx.doi.org/10.1108/02651339510103047

Guido, G., Prete, M.I., Tedeschi, P., \& Dadusc, L. (2010). Effects of Jewish-Italian animosity towards Arab products: the role of personality. Marketing Management Journal, 20(1), 1-18.

Guneren E., \& Ozturn A. (2008). Influence of ethnocentric tendency of consumers on their purchase intentions in north Cyprus. Journal of Euromarketing, 17(3-4), 219-231. http://dx.doi.org/10.1080/10496480802641096

Herche, J. (1992). A note on the predictive validity of the CETSCALE. Journal of Academy of Marketing Science, 20 (3), 261-264. http://dx.doi.org/10.1007/BF02723413

Herche, J. (1994). Ethnocentric tendencies, marketing strategy and import purchase behaviour. International Marketing Review, 11 (3), 4-16. http://dx.doi.org/10.1108/02651339410067012

Hoffmann, S., Mai, R., \& Smirnova, M. (2011). Development and validation of a cross-nationally stable scale of consumer animosity. Journal of Marketing Theory and Practice, 19(2), 235-251. http://dx.doi.org/10.2753/MTP1069-6679190208

Hsu, J.L., \& Nien, H-P. (2008). Who are ethnocentric? Examining consumer ethnocentrism in Chinese societies. Journal of Consumer Behaviour, 7(2008), 436-447. http://dx.doi.org/10.1002/cb.262

Huddleston, P., Good, L., \& Stoel, L. (2001). Consumer ethnocentrism, product necessity and Polish consumers' perceptions of quality. International Journal of Retail and Distribution Management, 29 (5), 236-246. http://dx.doi.org/10.1108/09590550110390896

Javalgi, R., Khare, V., Gross, A., \& Scherer, R. (2005). An application of the consumer ethnocentrism model to French consumers. International Business Review, 14, 325-344. http://dx.doi.org/10.1016/j.ibusrev.2004.12.006 
Kaynak, E., \& Kara, A. (2002). Consumer perceptions of foreign products: an analysis of product-country images and ethnocentrism. European Journal of Marketing, 36 (7/8), 928-949. http://dx.doi.org/10.1016/j.ibusrev.2004.12.006

Klein J.G., Ettenson, R., \& Krishnan, B. (2006). Extending the construct of consumer ethnocentrism: when foreign products are preferred. International Marketing Review, 23 (3), 304-321. http://dx.doi.org/10.1108/02651330610670460

Laroche, M., Papadopoulos, N., Heslop, L., \& Bergeron, J. (2003). Effects of subcultural differences on country and product evaluations. Journal of Consumer Behaviour, 2 (3), 232-247. http://dx.doi.org/10.1108/02651330610670460

Lee, W., Hong, J., \& Lee, S. (2003). Communicating with American consumers in the post 9/11 climate: an empirical investigation of consumer ethnocentrism in the United States. International Journal of Advertising, 22, 487-510.

Lindquist, J. D., Vida, I., Plank, R.E., \& Fairhurst, A. (2001). The modified CETSCALE: validity tests in the Czech Republic, Hungary and Poland. International Business Review, 10 (5), 505-516. http://dx.doi.org/10.1108/02651330610670460

Lynn, R. (1976). The sociobiology of nationalism. New Society, July, 11-14.

Maher, A.A., Clark, P., \& Maher, A. (2010). International consumer admiration and the persistence of animosity. Journal of Consumer Marketing, 27 (5), 414 - 424. http://dx.doi.org/10.1108/02651330610670460

Nguyen, T.D., Nguyen,T.T.M., \& Barrett, N.J. (2008). Consumer ethnocentrism, cultural sensitivity, and intention to purchase local products-evidence from Vietnam. Journal of Consumer Behaviour, 7, 88-100. http://dx.doi.org/10.1002/cb.238

O'Cass, A., \& Lim, K. (2002). Understanding the younger consumers' views of western and eastern brands Asia Pacific. Journal of Marketing and Logistics, 14 (4), 54-80. http://dx.doi.org/10.1108/13555850210764954

Oberecker, E.M., \& Diamantopoulos, A. (2011). Consumers' emotional bonds with foreign countries: does consumer affinity affect behavioural intentions? Journal of International Marketing, 19(2), 45-72. http://dx.doi.org/10.1509/jimk.19.2.45

Paswan, A., \& Sharma, S. (2004). Brand country of origin (COO), knowledge and COO image: investigation in an emerging franchise market. Journal of Product and Brand Management, 13 (3), 144-155. http://dx.doi.org/10.1108/10610420410538041

Phau, I., \& Chan, K.W. (2003). Targeting East Asian markets: a comparative study on national identity. Journal of Targeting, Measurement and Analysis for Marketing, 12 (2), 157-172. http://dx.doi.org/10.1057/palgrave.jt.5740105

Quester, P.G., Marr, N.E., \&Yeoh, P.S. (1996). Country-of-origin effects: an Australian experiment in shelf labelling. The International Review of Retail, Distribution and Consumer Research, 6 (1), 113-133. http://dx.doi.org/10.1080/09593969600000006

Reardon, J., Miller, C., Vida, I., \& Kim, I. (2005). The effects of ethnocentrism and economic development on the formation of brand and ad attitudes in transitional economics. European Journal of Marketing, 39(7/8), 737-754. http://dx.doi.org/10.1108/03090560510601743

Shankarmahesh, M.N. (2006). Consumer ethnocentrism: an integrative review of its antecedents and consequences. International Marketing Review, 23 (2), 146-172. http://dx.doi.org/10.1108/02651330610660065

Sharma, S.H., Shimp, T.A., \& Shin, J. (1995). Consumer ethnocentrism: a test of antecedents and moderators. Journal of Academy of Marketing Science, 23 (1), 26-37. http://dx.doi.org/10.1007/BF02894609

Shimp, T. A. (1984). Consumer ethnocentrism: the concept and a preliminary empirical test. Advances in Consumer Research, 11, 285-290.

Shimp, T., \& Sharma, S. (1987). Consumer ethnocentrism: construction and validation of the CETSCALE. Journal of Marketing Research, 24(3), 280-289. http://dx.doi.org/10.1007/BF02894609

Shone, S. J. (2004). Cultural relativism and the savage, the alleged inconsistency of William Graham Sumner. The American Journal of Economics and Sociology, 63 (3), 697-715. http://dx.doi.org/10.1007/BF02894609

Smith, M., \& Qianpin, L. (2010). The role of occupation in an integrated boycott model: a cross regional study in China. Journal of Global Marketing, 23(2), 109-126. http://dx.doi.org/10.1080/08911761003673421 
Steenkamp, J-P. E.M., \& Jong, M.G. (2010). A global investigation into the constellation of consumer attitudes toward global and local products. Journal of Marketing, 74, 18-40. http://dx.doi.org/10.1080/08911761003673421

Suh, T., \& Smith, K.H. (2008). Attitude toward globalization and country-of-origin evaluations: toward a dynamic theory. Journal of Global Marketing, 21(2), 127-139. http://dx.doi.org/10.1080/08911761003673421

Sumner, W. G. (1906). A study of the sociological importance of usages, manners, customs, mores and morals. Ginn and Company: New York.

Supphellen, M., \& Gronhaug, K. (2003). Building foreign brand personalities in Russia: the moderating effect of consumer ethnocentrism. International Journal of Advertising, 22 (2), 203-226.

Tripathi, S.N. (2009). An analysis of customer-pull factors and the process of store loyalty. Paradigm, XIII (1). 91-103.

Usunier, J-C., \& Lee, J.A. (2005). Marketing across cultures. Harlow: Prentice Hall.

Vida, I., \& Fairhurst, A. (1999). Factors underlying the phenomenon of consumer ethnocentricity: evidence from four central European countries. The International Review of Retail, Distribution and Consumer Research, 9 (4), 321-337. http://dx.doi.org/10.1080/08911761003673421

Wang, Y., \& Heitmeyer, J. (2006). Consumer attitude toward US versus domestic apparel in Taiwan. International Journal of Consumer Studies, 30 (1), 64-74. http://dx.doi.org/10.1080/08911761003673421

Wang, Y.J., Doss, S.K., Guo, C., \& Li, W. (2010). An investigation of the Chinese consumers' outshooting motives from a culture perspective. International Journal of Retail\& Distribution Management, 38 (6), 423-442. http://dx.doi.org/10.1080/08911761003673421

Witkowski, T., \& Beach, L. (1998). Consumer ethnocentrism in two emerging markets: determinants and predictive validity. Advances in Consumer Research, 25, 258-263.

Table 1. Major exports/imports markets for Jordanian products (2007-2009)*

\begin{tabular}{|l|c|c|c|}
\hline \multicolumn{1}{|c|}{ Region } & 2007 & 2008 & 2009 \\
\hline Arab countries & $1394 / 3211$ & $1849 / 4000$ & $1846 / 3165$ \\
\hline $\begin{array}{l}\text { European Union (Germany, } \\
\text { Italy, France and the U.K) }\end{array}$ & $111 / 2366$ & $182 / 2542$ & $107 / 2169$ \\
\hline Other European Countries & $14 / 598$ & $23 / 996$ & $19 / 568$ \\
\hline $\begin{array}{l}\text { NAFTA and South } \\
\text { American Countries }\end{array}$ & $895 / 734$ & $758 / 881$ & $629 / 988$ \\
\hline Non-Arab Asian Countries & $678 / 2696$ & $1476 / 3505$ & $880 / 2950$ \\
\hline Other Countries & $93 / 118$ & $142 / 138$ & $92 / 153$ \\
\hline
\end{tabular}

*Numbers in JD Million (JD1= 1.41USD)

Source: Central Bank of Jordan (CBJ), 2009 
Table 2. 10-item CETSCALE scores (Arabian version)

\begin{tabular}{|c|c|c|}
\hline & Item & Mean \\
\hline 1 & Only those products that are unavailable in Arab countries should be imported. & 4.68 \\
\hline 2 & Arab products, first, last, and foremost. & 4.03 \\
\hline 3 & Purchasing foreign-made products is un-Arabian. & 3.44 \\
\hline 4 & It is not right to purchase foreign products, because it puts Arabs out of jobs. & 3.85 \\
\hline 5 & A real Arab should always buy Arabian -made products. & 3.88 \\
\hline 6 & $\begin{array}{l}\text { We should purchase products manufactured in Arab counties instead of letting } \\
\text { other countries get rich off us. }\end{array}$ & 4.14 \\
\hline 7 & $\begin{array}{l}\text { Arab countries should not buy foreign products, because this hurts Arabian } \\
\text { business and causes unemployment. }\end{array}$ & 4.12 \\
\hline 8 & It may cost me in the long run but I prefer to support Arab products. & 4.25 \\
\hline 9 & $\begin{array}{l}\text { We should buy from foreign countries only those products that we cannot obtain } \\
\text { within Arab counties. }\end{array}$ & 4.46 \\
\hline 10 & $\begin{array}{l}\text { Arab consumers who purchase products made in other countries are responsible } \\
\text { for putting their fellow Arabs out of work. }\end{array}$ & 4.04 \\
\hline
\end{tabular}

7-point Likert format $\quad(7=$ very strongly agree, $1=$ very strongly disagree)

Table 3. Regression on CETSCALE (Arabian version)

\begin{tabular}{|c|l|c|c|c|c|c|}
\hline Model & & \multicolumn{2}{|c|}{$\begin{array}{c}\text { Unstandardised } \\
\text { Coefficients }\end{array}$} & $\begin{array}{c}\text { Standardised } \\
\text { Coefficients }\end{array}$ & $\mathrm{t}$ & Significant \\
\hline & & $\mathrm{B}$ & Std. Error & Beta & & \\
\hline 1 & $($ Constant $)$ & 39.518 & 3.822 & & 10.339 & $0.000 * * *$ \\
\hline & Gender & $-2.089-$ & 1.402 & $-0.078-$ & $-1.490-$ & 0.137 \\
\hline & Age & $-1.198-$ & .854 & $-0.078-$ & $-1.403-$ & 0.161 \\
\hline & $\begin{array}{l}\text { Marital } \\
\text { Status }\end{array}$ & 2.318 & 2.353 & 0.055 & 0.985 & 0.325 \\
\hline & Income & $-.524-$ & 0.557 & $-0.049-$ & $-0.942-$ & 0.347 \\
\hline & $\begin{array}{l}\text { Geographical } \\
\text { Location }\end{array}$ & 2.755 & 0.674 & 0.215 & 4.088 & $0.000 * * *$ \\
\hline
\end{tabular}

R Square $=0.068 \quad$ (Model statistics: $F=5.337$, Significant $=0.000$ )

$* * *, * * *$ refer to $0.000,0.05$ and 0.100 significant levels 